\title{
Study of intellectual capital in the academic area of the upper secondary level, in the state of Tabasco, to generate a proposal for improvement
}

\section{Estudio del capital intelectual en el área académica del nivel medio superior, en el estado de Tabasco, para generar una propuesta de mejora}

\author{
ELISEO-DANTES, Hortensia†*, MOREJON-SÁNCHEZ, Juana María, PÉREZ-PÉREZ, Iris Cristel and \\ GARCÍA-REYES, David Antonio
}

Tecnológico Nacional de México, Campus Villahermosa, Mexico.

ID $1^{\text {st }}$ Author: Hortensia, Eliseo-Dantes / ORC ID: 0000-0003-4006-4669, Researcher ID Thomson: F-6749-2018, PubMed ID: 6eb3adfd69824484b018f668c2670f109f08, CVU CONACYT ID: 411079

ID $1^{\text {st }}$ Co-author: Juana María, Morejon-Sánchez / ORC ID: 0000-0002-9930-181X, Researcher ID Thomson: ABE-28792020, PubMed ID: ad978b28511c360eaf67c0997bf9be92e908, CVU CONACYT ID: 362413

ID $2^{\text {nd }}$ Co-author: Iris Cristel, Pérez-Pérez / ORC ID: 0000-0003-3120-5597, Researcher ID Thomson: G-1891-2018, PubMed ID: 4153742f278c38045ef7e6c0e83c476d4208, CVU CONACYT ID: 843577

ID $3^{\text {rd }}$ Co-author: David Antonio, García-Reyes / ORC ID: 0000-0002-6083-079X, Researcher ID Thomson: D-4836-2018, PubMed ID: f210f5ebf4a27cfd142838f4b26e72a93e08, CVU CONACYT ID: 883868

\begin{abstract}
Objectives. Generate a comprehensive scenario that facilitates designing a proposal for the development of Intellectual Capital in Higher Secondary Education Institutions, in the state of Tabasco through an instrument that allows to measure intellectual capital, to make a comprehensive diagnosis and generate the proposal. Methodology. A methodological scheme is structured to establish a guide, which is useful for the author during the development of the research. The stages of the methodology are described, it should be clarified that each stage is divided by the period of time in which it is elaborated, Stage one: emergence of the idea, stage two: research protocol where the actors and experts are detected, stage three design of the instrument, stage four: obtaining the scenario and design of the proposal. Contribution. The study carried out in a decentralized public body of Higher Secondary Education, in such a way that it was possible to identify various limitations for obtaining Intellectual Capital, as well as areas of opportunity that could complement its obtaining. The results revealed that cultural, social and technological aspects originated little development of the system to obtain Intellectual Capital, this with the active participation of the experts
\end{abstract}

Intellectual capital, Experts, Institutions

\begin{abstract}
Resumen
Objetivos. Generar un escenario integral que facilite diseñar una propuesta de desarrollo del Capital Intelectual en Instituciones de Educación Media Superior, en el estado de Tabasco a través de un instrumento que permita medir el capital intelectual, para realizar un diagnóstico integral y generar la propuesta. Metodología. Se estructura un esquema metodológico para establecer una guía, que es útil para el autor durante el desarrollo de la investigación. Se describen las etapas de la metodología, cabe aclarar que cada etapa se divide por el lapso de tiempo en la que se elabora, Etapa uno: surgimiento de la idea, etapa dos: protocolo de la investigación donde se detecta a los actores y expertos, etapa tres diseño del instrumento, etapa cuatro: obtención del escenario y diseño de la propuesta. Contribución. El estudio ejecutado en un organismo público descentralizado de Educación Media Superior, de tal forma que fue posible identificar diversas limitantes para la obtención de Capital Intelectual, así como áreas de oportunidad que pudieran complementar su obtención. Los resultados revelaron que aspectos culturales, sociales y tecnológicos originaron poco desarrollo del sistema para la obtención de Capital Intelectual, esto con la participación activa de los expertos.
\end{abstract}

Capital Intelectual, Expertos, Instituciones

Citation: ELISEO-DANTES, Hortensia, MOREJON-SÁNCHEZ, Juana María, PÉREZ-PÉREZ, Iris Cristel and GARCÍAREYES, David Antonio. Study of intellectual capital in the academic area of the upper secondary level, in the state of Tabasco, to generate a proposal for improvement. Journal of Systems and Educational Management. 2020. 7-21:29-36.

\footnotetext{
* Correspondencia del Autor (horteed@ hotmail.com)

$\dagger$ Investigador contribuyendo como primer autor.
} 


\section{Introduction}

Information and knowledge is one of the most valuable and competitive weapons of our time. It is daring to say that knowledge is even more valuable than a large bank account or a large factory, since the companies that succeed in today's globalized world are those that have the best information and know how to use it efficiently.

Currently, this statement can be exemplified with various transnational companies that have a resounding success, which achieved their greatness, not because they were richer, but because they had something much more valuable, Intellectual Capital.

The concept of Intellectual Capital has been used in academic literature for many years; It is a topic on which the interest of organizations has grown rapidly in recent years. In this sense, (Bontis, 1998) affirms that "intellectual capital has been considered by many, defined by some, understood by few and formally valued by practically no one", which represents one of the most important challenges for today's companies.

(Bradley, 1997), argues that intellectual capital consists of the ability to transform knowledge and intangible assets into resources that create wealth both in companies and in countries. Similarly, intellectual capital is that knowledge that can be converted into benefit in the future and that is made up of resources such as ideas, inventions, technologies, computer programs, designs and processes (Edvinsson and Sullivan , 1996) and (Sullivan, 1999, 2001). Based on these definitions, it can be concluded that Intellectual Capital is the sum of knowledge that all the collaborators of an organization possess and give it a competitive advantage.

\section{Research background}

From the beginning, the concept of intellectual capital has been identified with the set of intangible assets that the company owns. Therefore, studies of intellectual capital have basically consisted of the study of intangible assets. Intangible assets have been analyzed from multiple perspectives (Marr, 2005), with the main purpose of providing evaluation and measurement models.
Bueno (2008, p.54), in his article "Genesis, concept and development of intellectual capital in the knowledge economy: A reflection on the Intellectus Model and its applications" adds aspects and characters that expand the knowledge and understanding of IC:

- It is a capital to some extent hidden or that is not usually represented in the financial statements.

- It is a capital of an intellectual or intangible nature that generates value for the company and represents the new wealth of organizations and nations.

- It is a capital that integrates different intangible assets, generated by a strategy based on knowledge flows or intellectual activities in the organization.

\section{Problem Statement}

Higher secondary education institutions, like all institutions that focus on education, in the state of Tabasco face several changes and academic challenges of great importance that are always focused on continuous improvement to provide quality education to students. young people from the region and all the actors involved in the process.

That is why, one of the reasons why it is desired to assess the impact that intellectual capital has within the entity, because this is one of its most valuable intangible assets, this being a fundamental factor to face these changes and institutional challenges. For this reason, it is important to implement a methodology that allows the value of intellectual capital. It is important that the institution is aware that its intellectual capital is present in all dependencies, and that it is necessarily and frequently having a direct impact on teachers and students of the different academic programs.

In recent years, the importance of intellectual capital within an organization has been gaining more and more force, and what it contributes and represents for its efficiency (Ríos, 2014). However, it must be clear that both public and private institutions, and society in general, totally lack measurement systems that are becoming more and more necessary for these new sources of wealth, as is the object of study (Ríos, 2014).

ELISEO-DANTES, Hortensia, MOREJON-SÁNCHEZ, Juana María, PÉREZ-PÉREZ, Iris Cristel and GARCÍA-REYES, David Antonio. Study of intellectual capital in the academic area of the upper secondary level, in the state of Tabasco, to generate a proposal for improvement. Journal of Systems and Educational Management. 2020 
For this reason, the value of intellectual capital and its identification became the object of study to be quantitatively measured in some way.

What is sought, in particular the teachers so that they can be providers of distinctive knowledge, contributing to the students of the institution and promoting through teaching, the ability to generate research, development and competitive growth.

\section{Hypothesis formulation}

- The cultural variable has a significant impact on the generation of intellectual capital in the academic area of an institution of upper secondary education in the state of Tabasco.

- The economic, technological, social and political variables partially affect the generation of intellectual capital in the academic area of an institution of upper secondary education, in the state of Tabasco.

- The environmental variable has a minimal impact on the generation of intellectual capital, in the academic area of an institution of upper secondary education, in the state of Tabasco.

\section{Contextual Framework}

To have a global vision of the object of study, in this frame of reference, the contextual frameworks at the international, national and local level will be exposed in order to identify factors and characteristics that each one of them present.

\section{International Context}

According to the World Economic Forum (2017 - 2018), in which 137 countries are compared with respect to the quality of education, Mexico is ranked 102

Every year in Davos, a small town in Switzerland, the highest international political figures, business leaders, intellectuals and journalists meet to analyze the problems that afflict our world.
Without a doubt, education plays an important role in the topics discussed. To which Salvador Alva, president of the Tecnológico de Monterrey, and participant in said international summit, presented himself to give testimony of the characteristics of education in the future according to international leaders.

Technology will change time management and free up more time by automating more functions, but at the same time it will be more difficult to capture the attention of students, so effective tools and programs will be necessary for learning (World Economic Forum, 2018).

For some years now, the research generated by China's universities and institutes has increased exponentially. An analysis developed by Times Higher Education in 2018, considers that by 2022 China could unseat the United States from the first position in scientific research, and consequently become one of the most innovative nations in the world.

David Swinbanks, founder of Nature Index affirms that China continues to dominate the world ranking, however, he emphasizes that "there are notable rising stars in other parts of the world, which come from Iran, Spain, United Kingdom, Switzerland, Japan, Luxembourg, Korea South, Austria, Norway, United States, Singapore, Finland, India and France".

\section{National Context}

In Mexico, the National System of Researchers (SNI) is one of Conacyt's most emblematic programs. Since 1984, the year of its creation, it has promoted human capital specialized in science, technology and innovation to dedicate full time to such activities. The researchers that compose it represent a group of vital importance for the development of knowledge in Mexico.

With more than three decades of existence, the SNI has grown significantly in quantitative and qualitative terms. Today it is one of the most important standards in science, technology and innovation in the country, taking into account the contributions of the SNI to these areas. 
It should be noted that Conacyt has the authority to organize and lead the SNI. In turn, there is a regulation that specifies its operating guidelines. Regarding its operation, the SNI works through an incentive scheme that allows the mobility of its members towards the highest levels of recognition in their academic careers. (Law of Science and Technology, 2002).

Regarding its structure, the SNI has three categories: Candidate for National Researcher, aimed at newly emerging researchers; II) National Researcher, which is divided into levels 1, 2 and 3, and finally III) Emeritus National Researcher, which represents an honorary appointment to researchers with a career and work widely recognized by the national and international scientific community.

\section{Methodology}

A methodological scheme is structured to establish a guide, which will be useful for the author during the development of the research project. The stages that have been worked on are described, it should be clarified that each stage is divided by the period of time in which it is elaborated. The system is considered with all its parts, which are described below.

\section{Stage I}

To establish the correct development of the idea, it is described in the following phases:

Thematic framework. Intellectual Capital in Organizations.

The thematic framework is the Intellectual Capital in Organizations, which is why it is induced that the systems in the organizations adopt a culture oriented to Intellectual Capital given the strong influence that it currently has as a competitive advantage.

General Topic: Intellectual Capital in Educational Institutions in the State of Tabasco. The general theme is to establish the study of Intellectual Capital in Educational Institutions in the state of Tabasco, since worldwide it is a Capital that generates added value and increases the efficiency and effectiveness, in this case, of the Education Sector. Specific Topic: Study of intellectual capital in the academic area of an Institution of Higher Secondary Education, in the state of Tabasco.
The specific topic is the study of Intellectual Capital in the academic area of an Institution of Higher Secondary Education, in the state of Tabasco, this under the approach of Intellectual Capital as the engine of evolution of the elements that make up the Institution, an aspect that is adopted during the development of the research protocol.

\section{Stage II}

This stage starts from the collection of information, this serves as the basis for the realization of the research protocol, while the contexts are structured simultaneously. Within the protocol, the problem is identified and raised, it is delimited, as well as the objectives of the research, the variables and the hypotheses are defined, it is complemented with theoretical evidence to support the study and follow-up.

On the other hand, the identification of the actors in the Institution of Higher Secondary Education is established through the organization chart, where you can clearly see who the leaders are, and their areas in charge, which are the following:

\section{- General Management.}

- Directorate of Planning, Programming and Budget.

- $\quad$ Academic direction.

- Directorate of School Registration and Control.

\section{- $\quad$ Administrative Direction.}

- Directorate of Financial Resources.

- Subdirectorate of Academic Planning.

\section{- $\quad$ Subdirectorate of Educational Services.}

For the selection of the experts, a round of interviews is carried out with each actor, in which some relevant aspects of the current contexts of the organization are discussed. 


\section{Stage III}

In this third stage, the frames of reference are developed, which are a collection of varied information, where there is a history of research related to the subject of study, methodologies, as well as suggestive lines of research, which are useful to reduce the margin error in the interpretation of the data and increase the chances of having results that are close to the reality of current contexts.

With the help of the literary review and thanks to the interviews with the actors and experts, we proceed to an analysis of the information obtained and the structuring of a comprehensive measurement instrument that allows evaluating the Intellectual Capital of the system, through various elements and subelements specially designed for the institution to study.

The comprehensive measurement instrument for Intellectual Capital (IIMCI), consists of ten elements which are described below:

Element 1: Measurements related to Higher Education Institutions as final customer.

Objective: To know and analyze all aspects related to Higher Education Institutions and how they impact on school processes.

Element 2: Comprehensive measurement of processes.

Objective: To comprehensively analyze each of the procedures that are developed in the processes and their relationship and interaction between them, to achieve the general objective.

Element 3: Alliance with suppliers.

Objective: Analyze the real support of relational capital in the matter of suppliers, to have a strategic support in the school.

Element 4: Structuring and management of documentation.

Objective: To know the aspects related to the integral management of the documentation.
Element 5: Training for the development of abilities and skills.

Objective: To know and interpret the factors that intervene in the development of abilities and skills at the school level.

Element 6: Benchmarking Process (Benchmarking).

Objective: Identify the opportunities that are found abroad and support the integral development of the school.

Element 7: Adaptability of processes.

Objective: Analyze the procedures included in the processes, and their relationship capacity, under a common purpose. level.

Element 8: Evolution of the managerial

Objective: Measure and analyze the potential of strategists, as well as their participation in the school.

Element 9: Development of Intellectual Capital.

Objective: Measure and analyze the potential of strategists, as well as their participation in the school.

Element 10: Productivity improvement scheme.

Objective: To evaluate in a general way the strategies for the continuous development of the school.

After having identified the organization's experts, meetings are scheduled to proceed individually with the application of the IIMCI, where each element is subjectively scored in a range of 1 to 100 in percentage of progress.

\section{Stage IV}

In addition to the IIMCI, there is the Structural Analysis methodology, which consists of the analysis of the structure of the system being studied, in this case: the Academic Area of an Institution of Higher Secondary Education, in the State of Tabasco. 
The methodology consists of three phases:

Phase 1: Starting from the independent variables identified in the research protocol: Social Variable, Economic Variable, Cultural Variable, Technological Variable, Environmental Variable, and Political Variable, factors are derived that make up the structure of the studied sector in terms of Intellectual Capital. The factors emerge with the help of the experts through the interviews conducted.

Phase 2: The factors are subjected to an analysis and deepened with bibliographic information. By means of the construction of a double-entry matrix, the perceptions of the experts are quantified through the interrelation of the factors, by means of a binary configuration, where the 1 represents that the factor that is being worked with "if "Has dominance over the other factor (the one being evaluated), and 0 represents that" there is no dominance over it.

\section{Analysis of results}

In the present investigation, we have worked hand in hand with the experts of the organization already identified in the previous stage. Meetings are scheduled to identify the determining factors in obtaining Intellectual Capital. However, before those involved were made aware of issues related to C.I., its dimensions, as well as context variables.

In the meetings, and with the help of brainstorming, a total of 23 Factors were identified, which can be viewed in Table 1, which are classified into the context variables, depending on which one derives from each.

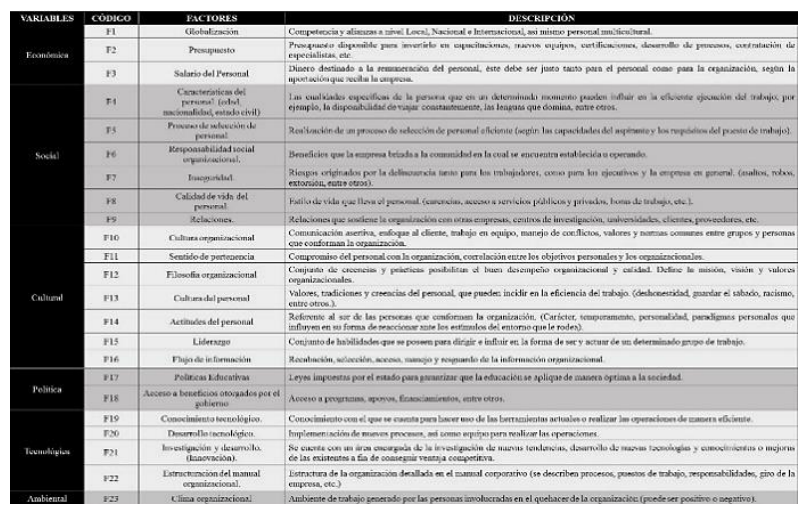

Table 1 Factors identified by experts

Source: Own elaboration, based on the opinion of experts (2020)

\section{Model for the Generation of Intellectual Capital}

For the follow-up of this research and given the structural analysis methodology, the focus of attention is paid to the first two areas represented in the level of Motor and Dependence, the Conflict Zone and the Power Zone, since they are those of greater impact for the system and are considered for the generation of the proposed model.

It is determined that the cultural, social, environmental and technological variables are the most influential in the aforementioned areas.

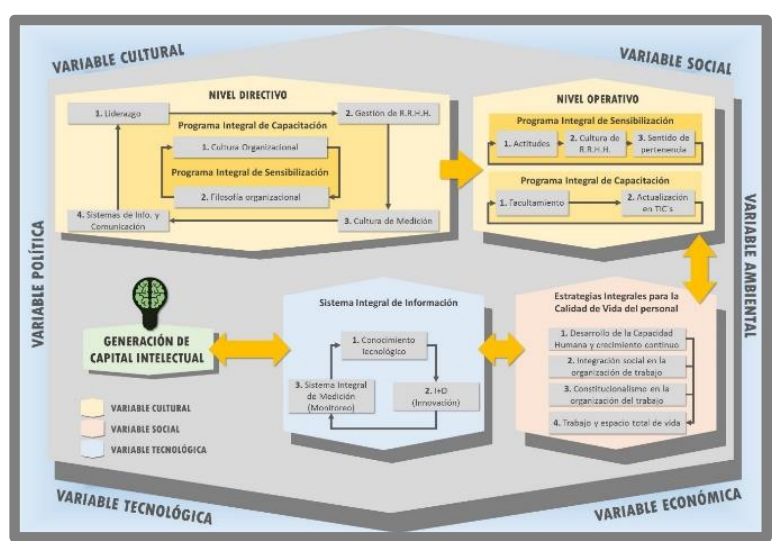

Figure 1 Development model for the generation of Intellectual Capital in an Institution of Higher Secondary Education

Source: Own elaboration, (2020)

\section{Interpretation of the Proposed Model}

For a stepped explanation of the proposed scheme, an interpretation divided into four stages is developed below.

\section{Stage I, Cultural Variable.}

Before beginning with the description of each of the stages, it is important to point out that the hexagonal shape of the Model refers to each of the context variables (Cultural, Economic, Social, Environmental, Technological, Political) that take place at moment of directly impacting the system, for the same reason, they are positioned on the outside, since they are permanently present.

It is correct to interpret the Model in the same sense that the clock's hands rotate, and this is where stage I begins, which is characterized by focusing on the Cultural variable, distinguished by the color yellow. 
It is considered that as a first instance the Executive Level is sensitized in aspects of Organizational Culture and Philosophy, and thus strengthened to continue with a comprehensive training program, starting with the development of Leadership and possess skills to be trained in correctly managing the Human Resource.

Then, it is proposed to develop and train leaders in the Culture of Measurement, relying on Information and Communication Systems as tools that enhance measurement methods.

Continuing with stage I, the procedure of comprehensive awareness and training programs is replicated but now at the Operational Level, starting with the development of good attitudes, customs, traditions, values and a sense of belonging, these aspects being pillars for the support of the training program, consisting of the empowerment and updating towards the new Information and Communication Technologies.

Given the results of the research, it has been determined that the previous items are of vital importance for the system, that they present certain deficiencies to obtain intellectual capital in the cultural field.

\section{Stage II, Social Variable}

Stage II focuses on supporting the areas of opportunity from the Social variable, distinguished by the color red.

\section{Stage III, Technological Variable}

Stage III is distinguished by the color blue and proposes three actions to strengthen the comprehensive information system in the system.

The first action is Technological Knowledge, which integrates technological tools that provide security in processes and procedures, optimize times and costs, as well as facilitate work and improve communication between the areas of the system and processes.

The second action corresponds to Research and Development (R\&D), the organization currently does not have this item, so it is a proposal that provides competitive advantage through innovation and invention.
Likewise, it allows to visualize future trends, so $R \& D$ is a fundamental element for the development of intellectual capital.

The third action proposes a comprehensive measurement system, since monitoring is the basis of strategic, operational and administrative control, in this way the quality and efficiency of all processes can be ensured, as well as allowing continuous growth and feedback.

\section{Stage IV, Generation of Intellectual Capital}

With the Model designed and following each of the stages proposed above, it ends with the obtaining of Intellectual Capital and makes the system aware of its importance, value and capacity, so that it can be used and increase its competitiveness. productivity and consequently quality.

\section{Conclusions}

At present, it is a fact that Intellectual Capital is a source of wealth and competitive advantage, so in the educational sector it is relevant to work on this aspect based on all available resources in order to achieve organizational competitiveness. The present study was in execution at a decentralized public body of Higher Secondary Education that takes place in the state of Tabasco, in such a way that it was possible to identify various limitations for obtaining Intellectual Capital, as well as areas of opportunity that could complement its obtaining. The results revealed that cultural, social and technological aspects have caused the little development of the system for obtaining Intellectual Capital.

Based on the results, the three hypotheses are refuted since they are partially fulfilled. Hypothesis number one proposed that the Cultural variable had a significant impact on obtaining IQ, on the other hand, hypothesis two, that the Economic, Technological, Social and Political variables had a partial impact, while in the third hypothesis the variable Environmental had a minimal impact. 
However, the cultural, social and environmental variable are those that have the greatest incidence in obtaining I.C., the Economic and Technological variables have a partial impact, while the political variable has a slight impact on the system.

\section{References}

Bontis, N. (1998). Intellectual capital: an exploratory study that develops measures and models. Management Dsecision, Volumen 36, $\mathrm{N}^{\circ} \quad 2, \quad$ pp. 63-76. https://doi.org/10.1108/00251749810204142.

- Cita dentro del texto: (Bontis, 1998).

Bontis, N. (2002): Managing and organizational learning system by aligning stocks and flows. Journal of Management Studies, Volumen 39, $\mathrm{N}^{\circ}$

\section{4.} https://doi.org/10.5465/APBPP.1999.27594761. - Cita dentro del texto: (Bontis, 2002).

Bueno, E. (2003). Modelo Intellectus: Medición y Gestión del Capital Intelectual, Documentos Intellectus. $\quad \mathrm{N}^{\circ} \quad 5, \quad I A D E$. https://www.academia.edu/7807104/Modelo_In tellectus_Medici\%C3\%B3n_y_Gesti\%C3\%B3n _del_Capital_Intelectual

- Cita dentro del texto: Bueno (2003).

Bueno, E.; Salmador, M. y Merino, C. (2008). Génesis, concepto y desarrollo del capital intelectual en la economía del conocimiento: Una reflexión sobre el Modelo Intellectus y sus aplicaciones. Estudios de Economía Aplicada, Volumen. 26, $\quad \mathrm{N}^{\circ}$ 2, pp. 43-63. https://www.redalyc.org/pdf/301/30113187003. pdf

Edvinsson, L., y Malone, M. (1997). Intellectual Capital. Realizing your Company's True Value by Finding its Hidden Brainpower. New York, NY: Harper Collins.

- Cita dentro del texto: Edvinson y Malone (1997).

Marr, B. (2005). Perspectives on Intellectual Capital: Multidisciplinary insights into Management, Measurement and Reporting. Elsevier Inc., Amsterdam.

- Cita dentro del texto: (Marr, 2005).
Ríos, G.; Bainbridge, A. y Jacobsen K. (2001). Intellectual Capital as a Strategic tool. Strategic and Leadership, Volumen 29, $\mathrm{N}^{\circ}$ 4, pp. 21-26. https://doi.org/10.1108/10878570110400116.

- Cita dentro del texto: Roos, Bainbridge, \& Jacobsen (2001).

World Economic Forum (2018). The Global Competitiveness Report 2017-2018. World Economic Forum. https://www.weforum.org/reports/the-globalcompetitiveness-report-2017-2018 - Cita dentro del texto: World Economic Forum (2017-2018). 